\title{
The Challenge for Women Academics: Reaching a Critical Mass in Research, Teaching, and Service
}

\section{E. LISBETH DONALDSON \& CLAUDIA G. EMES}

The University of Calgary

\section{ABSTRACT}

Contributions of academic women in Canadian universities are reviewed to determine whether their participation has reached a "critical mass." Specifically, scholarship about higher education, participation rates within academic ranks, and the frequency of administrative appointments are examined as illustrations of research, teaching and service, the traditional pillars that represent academic achievement. A fundamental assumption is that to achieve equity, a critical mass of women academics must promote and maintain gender sensitivity through these three pillars. Results indicate that, in a few instances, the minimum level of participation (35\%) was attained, but generally, critical mass has not yet been reached.

\section{RÉSUMÉ}

Les contributions des femmes dans les universités canadiennes ont été revisées à savoir si leur participation avait atteint la "masse critique." En utilisant les normes des Nations Unies, la "masse critique" est définie comme le pourcentage (35\%) nécessaire qui affecte la prise de décision de haut-niveau et qui a des effets de changements permanents. Spécifiquement, les bourses d'études supérieures, les taux de 
participation à l'intérieur des rangs académiques et la fréquence des nominations administratives sont examinés comme des illustrations de recherche, d'enseignement et de service, soit les piliers traditionnels que représente la réussite académique. L'hypotèse fondamentale est que pour réaliser l'équité, la "masse critique" de femmes à l;université doit promouvoir et maintenir la sensibilité des genres à travers ces trois piliers. Les résultats indiquent que dans quelques exemples, le niveau minimum de participation a été atteint, mais généralement, la "masse critique" n'a pas encore été atteinte.

\section{INTRODUCTION}

We don't so much want to see a female Einstein become an assistant professor. We want a woman schlemiel to get promoted as quickly as a male schlemiel. Bella Abzug (1977).

Gender sensitivity is a concept that acknowledges the differences between women and men (Diller, 1996). This understanding is important in postsecondary education because, according to the 1996 census, more women than men are completing degrees and postsecondary diplomas. As a result of enrolling in all types of postsecondary education, $51 \%$ of women in their twenties and $42 \%$ of men hold a degree or diploma (Duffy, 1998). Twenty-one percent of women aged 20 to 29 hold a university degree compared to $16 \%$ of men in the same age category. The participation rate of Canadian female undergraduate students increased from 33\% to $55 \%$ between 1968 and 1998 (Stalker \& Prentice, 1998).

The substantial gains women have made in acquiring postsecondary degrees raises the question of whether these women are learning in gender-sensitive environments. The thesis of this paper is that gender sensitivity results when participation rates of women in the core areas (research, teaching and service) reach a necessary critical mass to interact with the catalyst of awareness, making change inevitable and irreversible. The consequence of the full participation of women in academe would be a beneficial harvest of talent for society.

In this article, contributions of academic women in Canadian universities are reviewed to determine whether their participation has reached a 
"critical mass." Waves of progress made by women as they increasingly participate in higher education are identified. Given that the presence of women on campus is stronger in terms of numbers than at any time in history, the types of influence that these women hold is discussed. More specifically, scholarship about higher education, participation rates within academic ranks and the frequency of administrative appointments are examined as illustrations of research, teaching and service, the traditional pillars that represent academic achievement. Thus, they also are important avenues by which women gain the authority to effect change.

The following assumption about the means for achieving equity in the academy is fundamental. A critical mass of women academics must, through their collective effort, sustain core level accomplishments and introduce change by maintaining and promoting gender sensitivity within the institution. Critical mass, from a sociological perspective, is formed when the numbers of people necessary to adopt a new practice, product, or belief system also have sufficient awareness to kindle a chain reaction which persuades most people to adopt the change. In Megatrends for Women, Auberdene and Naisbitt (1992) suggest the sociological threshold for critical mass ranges between 5 and $20 \%$. The political impact requires higher levels.

Research has suggested that only when a minority increases to about $30-35 \%$ does it become strong enough to influence the fundamental group culture and form the alliances that can give it a significant impact on the whole. This argument indicates that the effect of women on the ambience and outcome of high-level decision-making will only be felt when their representation exceeds $35 \%$. (UN, 1992).

However, "Gerd Engman, a feminist politician in Sweden, believes that $20 \%$ participation is tokenism, at $30 \%$ women have a voice; but only when they reach $40 \%$ do they have a strong enough voice to bring about change" (Kirby, as cited in Dagg, 1998, p. 116). Obviously the percentages required to create critical mass vary.

Evidence of what might comprise a critical mass of women academics to create favorable change for women at universities indicates it is 
a complex amalgam of sociological and political components. Two may be enough.

In 1976 Karen Messing and Donna Mergler were the only full time women faculty members in the biology department at the University de Québec à Montréal. Together they lobbied for more women and were so effective that in 1998 women constituted one-third of the full-time faculty of 46 . (Kranias, 1998, p. 117).

Ideally, the proportion of women academic appointments would mirror the proportion of female undergraduates; given that they do not, research suggests they can effect change long before their numbers in the professoriate or administrative ranks equate the student participation rate. It is difficult to determine how quickly women might achieve such a high percentage. Based on the history of women's access to universities, predicting the point at which any critical mass is reached is more effective at a micro level of analysis. That is, perhaps critical mass at an assistant professorial level may be attained on a university-wide basis long before it is reached at the full professorial level. However, Aburdene and Naisbitt (1992) point out that a critical mass may be in place but it takes a spark to set it off. In this study, that spark is considered to be gender sensitivity, because the biological fact of womanhood does not necessarily result in a woman being aware of her social and political contexts. In fact, some male scholars are more gender-sensitive than many women in the academy (Schacht \& Ewing, 1998).

\section{Women Scholars: Participation Patterns and Concerns}

From a historical point of view, women's participation in the university is recent. Gillett (1998) identified four overlapping phases of women's association with higher education institutions, spanning more than 800 years. Women gained formal access to universities however, only during the past century.

Phase 1 of women's scholarship is characterized by the exclusion of women from formal education. The patriarchal entrenchment within the institution created an unyielding male dominance that lasted for centuries. The monastic values that shaped the evolution of universities 
from the 11th to the 19th centuries excluded females: women were not considered intellectually capable of academic pursuits; most did not learn Latin, the universal language of scholarly discourse.

During the Enlightenment, old traditions and hierarchies were undermined, thus the indomitable, male sanctuary was destined to change. Against resistance and continued devaluing of the role of education for women by highly educated men, colleges for women were organized (phase 2). By the end of the 19th century, women were admitted on a coeducational basis to universities. In Canada, the first instance of participation within the professoriate occurred when Lord Strathcona offered the principal of McGill University $\$ 50,000$ to use for appointing women academics. In 1912, Dr. Carrie Derick, the first female hired by the university, was appointed professor of morphological botany.

The third phase covers the last half of the twentieth century and is characterized by a rapid increase in the enrolment of women students, and gradually increasing numbers of women in the professoriate. However, the ratios are disparate. To illustrate, at the western Canadian university which will be used later as an example of participation rates in teaching, female academics in 1998/99, represented $27 \%$ of all full-time academic appointments, whereas the female undergraduate participation rate was $54 \%$ (R. Leason, personal communication, Nov. 30, 1998; The University of Calgary Fact Book, 1997-98).

As phase 4 commences, Gillett (1998) cautions that, without vigilant resistance, cycles of repression will marginalize women's research, their access to full-time teaching positions, and their administrative participation. It is a time to press for more women who will influence decisionmaking from a woman-centred perspective. During all four phases, awareness of the challenges faced by women scholars has been uneven and slower to develop than their participation rates in the academy. American intellectual historian, Gerda Lerner, notes that, unlike men, women's intellectual contributions are not individually acknowledged and passed from one generation to another because women have lacked access to formal education which institutionalizes such knowledge (Lerner, 1993). 
Often women do not become consciously aware of gender issues until they are traumatized. The tragic event that politicized many academic women was the 1989 Montreal deaths of 14 young women who were targeted because of their association with a postsecondary educational institution. However, the participation of women as career scholars in universities is primarily a sociological phenomenon, part of a larger movement based upon changed demographics and technologies that have transformed the female life cycle. Nevertheless, not all female academics are necessarily feminists, or aware of how their gender influences their careers. In other words, they (and many male colleagues) are not gender-sensitive; thus the necessary catalyst needed to effect change is not present, although frequency of participation in various aspects of academic life is increasing.

Canadian feminist commentary about participation in the academy may be summarized with reference to several influential publications although the discourse has been sustained in other various ways, including the articles used as a database for the meta-analysis section of this paper. Sociologist, Marlene Mackie, when exploring "Gender relations in Canada: Further explorations" (1991, pp. 10-12). noted that the situation during the 1970s was one in which women academics faced structural and attitudinal barriers such as a lack of day-care centers and exclusion from decision-making committees. During the 1980s, although many universities produced reports about the status of women in academia and formulated equity policies, a contracted economy resulted in a squeezing effect that generally impeded change. Fewer women had tenured status, more earned lower salaries even when ranks were equal, and more were involved in teaching and advising students rather than in research and administration. Not surprisingly, their published work occasionally commented upon their situations.

Physical scientists Dagg and Thompson (1988) identified a number of issues at various campuses and made specific suggestions for change. Research geared toward male concerns excludes more than women scholars, it does not unearth more knowledge about women; therefore research about women should be viewed as a serious and valid undertaking, and be as likely to win a professor tenure as is doing research on any other topic 
(p. 120). Teaching and course content needed to be monitored for sexual discrimination and exclusion. University services must be extended to include issues of safety, harassment, and childcare responsibilities.

Psychologist Caplan (1993), pointed out that development of policies does not eliminate subtle forms of bias including the myth that with affirmative action, standards are lowered to hire women. She concludes with specific guidelines about how change might be effected, so that the cumulative weight of small slights does not result in depreciated scholarship and scholars. Literary scholar Shick (1994) articulates a feminist pedagogy that encourages thoughtful reflection about learning within male-oriented (con)texts, and the articulation of woman-centred knowledge derived from small acts of courage. Higher Education specialist Stalker and her Women's Studies colleague Prentice edited the book entitled, Illusion of Inclusion: Women in Postsecondary Education (1998), with articles that emphasize the continuing pervasive marginalization of women. The book concludes with specific, woman-friendly recommendations based upon the Canadian Federation of University Women (CFUW) report (Saunders, Therrien, \& Williams, 1998).

During the last two decades, the ongoing concerns have continued to be lack of support services, exclusionary course content, inclusionary language, harassment and safe environment issues, salary equity and hiring and tenure. In spite of these continuing structural and attitudinal barriers, women scholars have produced, published and transformed many aspects of the world of scholarship. Getting the Word Out by Andrew (1989), Gender Bias in Scholarship by Tomm and Hamilton (1988), and On the Treatment of the Sexes in Research by Eichler and Lapointe (1985), resulted from conferences and symposia that stimulated dialogue about the quality of feminist-scholarship in Canada.

Nevertheless, this discourse is not mainstream. Education Canada? Higher Education on the Brink (Paquet \& von Zur-Muehlen, 1987) is dedicated "to our grandchildren" whose lives will be affected by the decisions of the National Forum on Postsecondary Education, Saskatoon, 1987. The book has but three comments from women: one from a student; one from an assistant professor of management, and one from an administrator. The Forum did not discuss any aspect of women 
in academia except their access to those disciplines where they are under-represented - more of an economic concern for the institution than one of talent pool development within a discipline. The book, Academic Futures, Prospects for Postsecondary Education (Shere \& Duhamel, 1987) contains one chapter authored by a woman acknowledging the influence of the subculture of the woman's movement. Bankrupt Education, the Decline of Liberal Education in Canada (Emberley, \& Newell, 1994) argues that millennial enthusiasm for postsecondary reform eclipses a deeper spiritual malaise, yet the authors attack feminist attempts to articulate a woman-centred perspective and ignore all of Western intellectual heritage that was authored or imaged by females.

In The New Agenda for Higher Education, Choices Universities Can Make to Ensure a Brighter Future, Renner (1995) promotes an alternative viewpoint:

...feminism, the philosophical foundation of that yet-to-be respected academic program of women's studies, may very well hold much of the wisdom necessary to meet the modern management challenge. (p. 135)

This discussion is sufficiently contentious that a vocabulary of key words has evolved (Mandell, 1998). "Feminism" is a problematic word because not all women in academia identify with the connotation: it seems to represent an angry negative stance. Nevertheless, scholars who think about the role of women in the academy usually arrive at an acceptance of the term because it reflects not only a political stance encompassing the momentum for sociological change, but theoretical constructs that frame understandings of issues. "Gender" is a term emphasizing malleable differences between women and men, while biological essentialism is usually defined as "sexual determinism." "Gender-sensitive" is a term that acknowledges gender differences better than "gender-neutral" (Martin, 1994). "Woman-centred" refers to a psychological orientation within which girls and women are likely to make more creative and original scholarly contributions (Donaldson, 1997). All of these terms currently are used frequently in any discourse about the roles of women in research, teaching, and service. While terminology and language remain unclear, language issues will likely recede 
from the foreground as the development of women scholars, an irreversible trend, continues throughout most of the world.

\section{Participation Rates: Research, Teaching, and Service}

In the academy, research productivity is measured by counting peerreviewed published journal articles. For example, in the United States the female rate of publication was $60 \%$ that of males during the late $1960 \mathrm{~s}$. However, by the late 1980s and early 1990s it had increased to the range of 75 to $80 \%$ (Xie \& Shauman, 1998). Schneider (1998) reported that in 1989, according to the Higher Education Research Institute, $0.7 \%$ of university women had published more than 51 articles compared to $2 \%$ of men; $20 \%$ of academic women had never published a journal article compared to $7 \%$ of their male counterparts. These figures were consistent across disciplines, including those where women have been traditionally awarded the majority of Ph.D.s. Without raising quality versus quantity arguments, it is refreshing to note that the productivity gap is closing even though most women scholars are junior academics.

A long-range plan for achieving equity in women's participation in the academy was proposed by Backhouse (as cited by Blakely, 1989). Based on participation rates of $17 \%$ in $1985-86$ she set out an aggressive employment plan that would lead to a 50-50 balance in the gender composition of faculty in Canadian universities by the year 2000. Part of her proposal included a five-year review process in which those who failed to reach an appropriate standard in research, teaching, and administration would be dismissed. Using a different set of assumptions, Blakely analyzed Backhouse's proposal to determine what proportion of vacancies created between 1985 and 2000 would have to be filled by women in order to achieve such a 50-50 gender balance by the target date. He stated that to achieve this goal, women would have to fill $92 \%$ of all vacant faculty positions. He further projected that by 2000 , with equity practices in place, women's participation would be at the level of $35 \%$. In fact, downsizing has slowed momentum, and neither Backhouse's nor Blakely's projections have been realized.

As participation rates increase, more women are emerging as leaders. Women bring a useful engendered type of knowledge to senior 
academic administration given their experiences, and thus they provide complementary leadership. Serving as presidents and vice-presidents, they are gendered role models who contribute to a new image of the academy, also extending insights as 'guardians of knowledge." However, in 1997 only 7 of 81 presidents were women, the number of vice presidents had decreased from 13 to 11 , and there were 16 associate vice presidents: the number of senior women academic administrators was $12 \%$ of the total (Sheinin, 1998, p. 105).

Participation on committees presents a different challenge. Rees (1998) provides an example of women doing double-duty service. Of an eight-person selection committee, only one of six faculty members was female, and this one woman also served as equity officer for the university. Both student representatives were female. Women comprised 55\% of the 325 applications for eight positions. Three women were hired. This case illustrates several important points. Women scholars do double duty because low numbers result in increased service on committees. In this case, the female faculty member was also the equity officer and one of the three hirees was also a visible minority. The service role extended to students, both of whom were female. Although women applicants comprised a majority, they constituted a minority of the hirees. Nevertheless, when women consciously mentor, they can increase the percentage of female hirees, especially when the talent pool is sufficiently large.

\section{METHOD}

Data were obtained for each of the three core areas of academic responsibility through selection of illustrative examples of relevant achievements and issues. Three types of data bases were developed. To assess the research contributions of women to higher education in Canada, a meta-analysis was conducted of articles published and books reviewed by The Canadian Journal of Higher Education (CJHE) during a ten-year period, 1987 to 1997 . To assess teaching participation rates, a snapshot was composed of rank and frequency demographics at one teaching and research university. To assess service levels, results from a 
sample of the Association of Universities and Colleges of Canada (AUCC) Universities 1998 Telephone Directory provided an administrative appointment profile for ten major universities.

\section{Research}

The CJHE was established in 1970:

...to serve as a medium of communication among persons directly involved in higher education in Canada, or deeply interested in this field. The principal focus is on Canadian higher education, but not to the exclusion of developments in other countries which are of concern to the Canadian scene (1997, inside front cover).

Published three times per year, the CJHE is indexed internationally, peerreviewed, supported by volunteer faculty editors, and managed by an Advisory Board and a paid editorial assistant. The CJHE represents the Canadian Society for the Study of Higher Education, and receives grants from the Social Sciences and Humanities Research Council of Canada.

In the meta-analysis of 32 CJHE issues (1987-1997), a matrix was used to analyze percentages of scholarly participation by women academics in three major categories: authors, editors, and book reviewers. Authors of articles were classified in three ways: single author, first author of multiple authors, contributing author of multiple authors. Three sub-categories under editing included: the editorial board, advisory board and contributing editors. Book reviews were analyzed according to eight sub-categories: reviewer of the book, and for each book reviewed: single author, first author of multiple authors, contributing author of multiple authors, single editor, first editor of multiple editors, contributing editor of multiple. Also classified in the matrix was direct reference in any title to women and women's issues, such as equity.

Content analysis of the various contributions was first divided into two categories: articles or book reviews that directly referred to gender issues in the title; and articles or book reviews with content about other issues which women authored or reviewed. Each category was further divided into thematic units based upon key words in the title. Although the thematic units overlapped, they were not identical. 
In addition, the CJHE recognized the achievements of members of the Canadian Society for the Study of Higher Education (CSSHE) by listing the names of notable contributors acknowledged with honours and awards. These included names of past presidents, distinguished members, research awards, the Sheffield Award for "most excellent" article of the year, and dissertation awards.

\section{Teaching}

It is accepted knowledge that there are more women in the lower academic ranks. Therefore, to assess participation rates, a snapshot approach of one teaching and research university in Canada was used to develop a teaching profile. The 1997-98 year was analyzed because a large number of women were converted from long-term sessional to tenured, full-time instructor positions during that period at this institution. Frequency of participation by rank was identified according to fulltime appointments with tenure or tenure-track.

\section{Service}

An examination of participation rates of women in senior academic administration using the AUCC directory yielded the service data base. From a total of 89 , ten well-established universities (history of approximately 50 years or more) were selected on the basis of one from each province. Percentage frequency rates of administrative appointments were collected for positions of President, Vice-Presidents, Associate/Assistant Vice-Presidents, Deans, Department Chairs, Directors of Schools, Directors of Institutes and Registrars.

\section{RESULTS}

\section{Research}

The percentages of women who were identified in various scholarly roles according to publication in the CJHE from 1987 to 1997 are presented in Table 1 . The highest publication rate (43\%) was as contributing author to journal articles. In rank order, other publication rates were as follows: first author of a book (35\%), first author of an article (32\%), 
Table 1

Roles of Women Identified in the CJHE from 1987 to 1997

\begin{tabular}{|c|c|c|c|c|c|}
\hline ARTICLES & $\%$ & EDITORIAL & $\%$ & \multicolumn{2}{|c|}{ BOOKS REVIEWED \% } \\
\hline Single author & 29 & Editorial board & 54 & Book reviewer & 32 \\
\hline First author & 32 & Advisory board & 39 & Single editor & 39 \\
\hline $\begin{array}{l}\text { Contributing } \\
\text { author }\end{array}$ & 43 & $\begin{array}{l}\text { Contributing } \\
\text { editor }\end{array}$ & 32 & First editor & 21 \\
\hline \multirow[t]{5}{*}{$\begin{array}{l}\text { Reference to } \\
\text { women in title }\end{array}$} & 9 & & & $\begin{array}{l}\text { Contributing } \\
\text { editor }\end{array}$ & 32 \\
\hline & & & & Single author & 19 \\
\hline & & & & First author & 35 \\
\hline & & & & $\begin{array}{l}\text { Contributing } \\
\text { author }\end{array}$ & 25 \\
\hline & & & & $\begin{array}{l}\text { Reference to } \\
\text { women in title }\end{array}$ & 7 \\
\hline
\end{tabular}

single author of an article (29\%), contributing author of a book $(25 \%)$ and single author of a book (19\%). Only $9 \%$ of article titles reference women.

In the role of editorship, women served primarily on the editorial board (54\%), followed by the advisory board (39\%) and as contributing editors $(32 \%)$. In the reviewer role, $32 \%$ were women. The highest percentage was as single editor (39\%) and then as first author (35\%). In the books reviewed, women were more often a contributing editor $(32 \%)$ rather than a first editor $(21 \%)$. They were also more frequently a contributing author (25\%) than a single author (19\%). Only $7 \%$ of the reviewed book titles referenced women.

Of the 111 citations which women authored or reviewed, less than one-third were all-female contributions. The majority of citations (91) addressed issues other than gender specifically in the title. Emergent themes included: policy (33), students (25), teaching (24), working 
conditions (8), and achievement (1). Policy concerns included bilingualism, the changing role of the university in society, and faculty reactions to various planning initiatives. Student topics included minority groups, cognitive development, evaluation of achievement, and retention and attrition. Teaching issues involved improvement strategies in delivery and learning techniques. Topics on working conditions included faculty career development. The single acknowledgement of achievement was a book review about a prominent male scientist.

With respect to scholarship in the CJHE, critical mass (35\%) was attained only when women were one of the contributing authors. Women were more active on the editorial and the advisory board of the CJHE surpassing the minimum criterion for critical mass. Regarding reviewed authorship, critical mass was reached in only two areas: single editor of a book and first author.

Only 20 of the 111 citations directly discuss gender issues: equity and employment (9), students (4), working conditions (6), and achievement (1). Equity and employment concerns included articles about career goals of female faculty, university as an employer of women in various ranks, and gender discrimination in salaries. Student issues that were addressed involved retention in science disciplines, sociopsychological variables and achievement, and support for re-entry students. Working conditions included topics such as "date rape" and the "chilly climate." The only article on achievement acknowledged early women academics at a particular university. When gender issues were reviewed, all book reviewers were female, and $50 \%$ of the authors were female. Four of six single authors about the topic were women.

Since the inception of the Canadian Society for the Study of Higher Education (CSSHE), the majority of recipients of honours and awards have been men. Table 2 reveals women's participation rates where $10 \%$ have been president, $6 \%$ named distinguished member, and $14 \%$ had received a research award. In contrast, $40 \%$ of the "most excellent" articles and $69 \%$ of the dissertation awards were women. 
Table 2

Percentage of Women in Recognition of Achievements of Members of the CSSHE from 1987-97

\begin{tabular}{lc}
\hline ACHIEVEMENT & $\%$ of total \\
\hline President & 10 \\
Distinguished Member & 6 \\
Research Award & 14 \\
Sheffield Award & 40 \\
Dissertation Award & 69 \\
\hline
\end{tabular}

\section{Teaching}

Table 3 illustrates the number of women within each rank of tenure track position at a Western Canadian research university in 1997-98. Within the professorial ranks, the highest rate (43\%) was present at the level of Assistant Professor, decreasing to 30\% of Associate Professors and further declining to $12 \%$ of Professors. Similarly, $72 \%$ of Instructor I appointments were women, followed by $55 \%$ at Instructor II level and $33 \%$ at the level of Senior Instructor.

With respect to achieving the baseline of critical mass, women in teaching were clustered at the lower levels: Assistant Professor, Instructor II and I.

\section{Service}

Table 4 presents results of surveying a sample of universities in the 1998-99 AUCC directory listings. Of the nine senior administrative roles, women comprise $30 \%$ of the presidencies, $9 \%$ of vice-presidents, $30 \%$ of the associate vice-presidents, $26 \%$ of deans, $12 \%$ of department chairs, $34 \%$ of directors of Schools, $13 \%$ of directors of Institutes and $40 \%$ of registrars. The gender of a number of administrators was unknown because either their initials or first names did not reveal whether they were women; these were clustered in departmental chairs and directorships. The only role to reach critical mass was registrar. 
Table 3

Percentage of Women in Academic Ranks in 1997-98

\begin{tabular}{ll}
\hline RANK & $\%$ of total \\
\hline Professor & 12 \\
Associate Professor & 30 \\
Assistant Professor & 43 \\
Senior Instructor & 33 \\
Instructor II & 55 \\
Instructor I & $72 *$ \\
\hline large number of conversions from sessional ranks & \\
\hline
\end{tabular}

Table 4

Percentage of Senior Women Academic Administrators in Ten Canadian Universities

\begin{tabular}{lc}
\hline ADMINISTRATOR & \% of total \\
\hline President & 30 \\
Vice President & 9 \\
Assistant Vice President & 30 \\
Dean & 26 \\
Department Chair & 12 \\
Director of a School & 34 \\
Director of an Institute & 13 \\
Registrar & 40 \\
\hline
\end{tabular}




\section{DISCUSSION}

Although academic appointment rates of women ideally ought to reflect female student participation within universities, they do not and, in fact, fall noticeably short of this target. Increasing the raw number of female academics, however, does not guarantee the translation of universities into gender-sensitive environments. In concert with more females, an awareness and understanding of gender in relation to higher education must be present. The core academic responsibilities of research, teaching, and service are avenues that women can use, through their presence and awareness, to create more gender sensitivity.

As creators of knowledge, academics know that publishing peerreviewed articles represents mature scholarship. All disciplines assess scholarship by reviewing publication records. However, the extent to which single-authored versus collaborative authorship is valued varies by discipline. The data-base used here suggests that women academics collaborate more frequently than do men. Women were much less likely to be single authors or first authors of articles than they were to be one of several contributing authors. The implication is that these women authors are not likely to be mature researchers. Furthermore, very few articles directly addressed women's issues in the title. These results suggest that there are limited attempts to raise gender-sensitive consciousness by writing for journals. This observation raises questions about whether women scholars increasingly address gender issues as they mature, whether they remain gender illiterate throughout their careers, or whether they are aware but choose not to do scholarship in this area.

If scholarship activities are analyzed with reference to service versus productivity, the highest participation rates in CJHE by women are in the scholarly service role. The majority $(54 \%)$ of those who served on the Editorial Board over the ten-year period were women; the percentage of those on the Advisory Board (39\%) was more than critical mass. These percentages are considerably higher than the publication (productivity) categories. Percentages in reviewing roles were also higher than those of authors of articles. The numbers of women academics that reviewed books approximated critical mass (32\%). Of the reviewed books, the highest 
percentages reflected editorial rather than authoring scholarship. In fact, the single-editor percentage of participation was high (39\%), given that it is more difficult to review the various perspectives within edited books as opposed to those of single authors. However, the number of singleauthored books written by women was encouragingly high $(35 \%)$; the contributing authorship percentage was lower (25\%).

Thus the scholarship profile that emerges is more strongly one of servant to than creator of knowledge. Women academics were more active in sustaining the publication of the journal than in authoring articles; also, they were more likely to be reviewers and editors rather than book authors.

Women rarely study the participation of women in the academy. This pattern reflects the marginalization of scholarship about women and by women scholars. Only $16 \%$ of the total number of articles and book reviews specifically addressed gender issues in the academy despite increases in female enrollments that have sustained university admission levels and changed the culture of many disciplines. When gender issues were the topic of an article or book or review, women scholars were more likely to have been involved than were men, and equity and employment issues were priorities. Policy and teaching concerns involved both women and men scholars. However, it is also worth noting the minimal scholarship about biographies of eminent Canadian scholars or histories of higher education in Canada. Thus, there is little evidence of awareness of achievement, role modeling, and innovation although the contributions have never been greater.

Further, when the activities of the Society for the Study of Higher Education are assessed, the participation of women academics at senior levels is very low: of a total of 28 presidents three were women, one of whom served two terms. Of 15 distinguished members, only one woman was named. For seven research awards, one woman was named. Of five annual Sheffield awards, two were awarded to women. By contrast 9 of 13 dissertation awards went to women. Thus, once again, the profile of marginalized scholar and marginalized scholarship becomes evident. The promise of excellence at junior levels without the subsequent harvest of talent at more senior levels is an echo of what happens within the 
compulsory school system. Reasons for the withering are very complex, and probably include such factors as the woman's life cycle, discrimination and gender-blindness within the system, and personal decisions to pursue other goals.

For the purposes of examining teaching, percentage frequencies of participation rates in the instructor and professorial ranks revealed predictable trends. Women are clustered at lower ranks. The numbers were compounded by the conversion of a large number of sessional appointments to the instructor and professorial ranks at the commencement of the 1997-98 academic year in this particular year, thus making the trend very clear. At the levels of assistant professor, instructor I and instructor II, percentages of women academics were well past minimal levels of critical mass, signifying the talent pool is available. However, the proportion of women at more senior levels declines dramatically, and is lower than minimal levels for critical mass. These results reflect the relatively recent increase of women choosing academic careers, and also the life cycle. As a consequence of family commitments, it is not unusual for women to spend longer completing graduate and post-doctoral work. Because of being place-bound, many choose part-time and/or instructorlevel employment. As a result, their progress through the ranks is slower and may arrest before they reach the highest levels. Despite the prevalence of this career pattern, the woman's life cycle is rarely taught in any discipline at universities. Women often provide anecdotal evidence in informal conversations, but rarely is the impact formally researched or taught, so that the development of awareness, appropriate mentorship, and career planning affects high-level decision-making at personal and professional or institutional levels.

Women as leaders in the academy can also contribute to the development of gender-sensitivity, and when assuming senior academic administrative roles, women not only provide service, but they have a unique opportunity as role models to influence attitudes and insights about gender. In the service role area, as with research and teaching, women's levels of participation fall short of critical mass. The exception is the role of registrar $(40 \%)$, but interestingly, registrars at some universities are not academic appointments. The percentage of women Directors of Schools 
(34\%) approaches critical mass; these schools generally house such women-dominant professional programs as nursing, nutrition and food services, social work and specialized institutes. Of interest is the relatively high percentage of women presidents. However, our data also indicate that the percentage of senior administrators below the level of president is considerably lower. This contrast suggests a lack of succession planning regarding the necessary training and experience required for promotion to senior levels of administrative service. As was noted in the literature, women migrate toward such service roles as associate vice-president, tending to be appointed more in areas that are supportive rather than those that offer policy development and power distribution experience, as would be the case with department heads.

\section{CONCLUSION}

The concept of critical mass, using the United Nations suggested minimum percentage necessary for political action, has been a useful analytical tool to assess core academic participation by women scholars. The necessary condition of gender-sensitivity as the catalyst for action was not uniformly demonstrated in this study of research, teaching, and service participation levels. In few instances, the minimum of $35 \%$ was attained, and the amount of scholarship that directly addressed gender issues was very low.

The profile of productivity and participation makes clearer the activity of the increasing pool of talent that is resulting from dramatic increases in student enrollment patterns during the past twenty years. The loss of such talent to the academy is also clearer. Few women scholars are productive as single authors or as first author; more are active in scholarly service such as editing and reviewing. Few achieve recognition as scholars beyond the dissertation. Few women become full professors; the majority of women are clustered at instructor levels. Although more women have become high-profile senior administrators, evidence of succession planning is not obvious at lower levels of appointment. Thus, the necessary percentages for political action rarely attain the minimal level of $35 \%$. 
It also seems unlikely that the catalyst of awareness, gender-sensitivity, is present in many instances. Scholarship that directly addresses gender issues is minimal, and that which exists is mostly conducted by women scholars. Thus, in addition to a lack of generation, there is a lack of dissemination throughout the academy.

Research, teaching, and service are the fundamental pillars of an academic appointment, and all three must reach higher levels of female participation before change is irreversible. In addition to reaching a critical mass percentage through raw numbers, some sort of balance must be attained in each section of the "triad" of responsibilities so that gender sensitivity is infused into the academy. Finally, the number of academics who have an awareness of gender issues must be sufficiently high to provide a catalyst for change. This is a more subtle argument than merely increasing our numbers. It addresses the concept of awareness, and more specifically, of self-awareness for both female and male academics. It raises questions about what is included in the curriculum of various disciplines: how inclusive is the material, what are the learning dynamics, who controls the research agenda. Therefore, the challenge remains, but it is a more subtle nuance, shadowed by a simplistic reliance upon increased levels of uneven participation rates in research, teaching, and service.

\section{References}

Andrew, C. (Ed.). (1989). Getting the word out. Ottawa, ON: University of Ottawa Press.

Aburdene, P., \& Naisbitt, J. (1992). Megatrends for women. New York, NY: Random House.

Blakely, J. (1989). What should the goals be: Employment equity for female faculty in Canada. The Canadian Journal of Higher Education, 19, 29-48.

Caplan P. (1993). Lifting a ton of feathers: $A$ woman's guide to surviving in the academic world. Toronto, ON: University of Toronto Press.

Dagg, A., \& Thompson P. (1988). MisEducation: Women and Canadian universities. Toronto, ON: Ontario Institute for Studies in Education. 
Dagg, A. (1998). Hiring of women at Canadian universities: The subversion of equity. In J. Stalker \& S. Prentice (Eds.), The illusion of inclusion: Women in postsecondary education. Halifax, NS: Fernwood Publishing.

Diller, A., Houston, B., Morgan, K.P., \& Ayim, M. (1996). The gender question in education: Theory, pedagogy, \& politics. Boulder, CO: Westview Press, Inc.

Donaldson, E.L. (1997). Images of the goddess: Spiritual aspects of the women's life cycle. Canadian Woman Studies. 17(1), 36-39.

Duffy, A. (1998, April 15) 1996 Census: Women make huge educational gains. The Calgary Herald, p. A1.

Eichler, M., \& Lapointe, J. (Eds.). (1985). On the treatment of the sexes in research. Social Sciences and Humanities Research Council, Canada.

Emberley, P., \& Newell, W. (1994). Bankrupt Education, the decline of liberal education in Canada. Toronto, ON: University of Toronto Press.

Gillett, M. (1998). The four phases of academe: Women in the university. In J. Stalker \& S. Prentice (Eds.), The illusion of inclusion: Women in postsecondary education (pp. 36-47). Halifax, NS: Fernwood Publishing.

Kranias, G. (1998). Women and the changing faces of science. In M.G. Ainley (Ed.), Despite the odds. Montreal: Vehicule. In J. Stalker \& S. Prentice (Eds.), The illusion of inclusion: Women in postsecondary education. Halifax, NS: Fernwood Publishing.

Kirby, S. (1998). The 40 percent solution. Horizons, Fall:9. In J. Stalker \& S. Prentice (Eds.), The illusion of inclusion: Women in postsecondary education (p. 116). Halifax, NS: Fernwood Publishing.

Lerner, G. (1993). The creation of feminist consciousness. Oxford: Oxford University Press.

Mackie, M. (1991). Gender relations in Canada: Further explorations. Toronto, ON: Harcourt Brace.

Mandell, N. (1998). Feminist issues: Race, class, and sexuality. Scarborough, ON: Prentice Hall Allyn Bacon, Canada.

Martin, J.R. (1994). Changing the educational landscape: Philosophy, women, and curriculum. New York, NY: Routledge.

Paquet, G., \& von Zur-Muehlen, M. (Eds.). (1987). Education Canada? Higher education on the brink. Ottawa, ON: Canadian Higher Education Research Network. 
Renner, K.E. (1995). The new agenda for higher education; Choices universities can make to ensure a brighter future. Calgary, AB: Detselig Enterprises.

Rees, R. (1998). An equitable recruitment and hiring process in the academy? A case study. Unpublished manuscript.

Schacht, S., \& Ewing D. (1998). Feminism and men: Reconstructing gender relations. New York, NY: New York University Press.

Saunders, M., Therrien, M., \& Williams, L. (1998). Creating the "womanfriendly" university: A summary of the CFUW report. In J. Stalker J. \& S. Prentice (Eds.), The illusion of inclusion: women in postsecondary education (pp. 216-230). Halifax, NS: Fernwood Publishing.

Schick, C. (1994). The university as text: Women and the university context. Halifax, NS: Fernwood Publishing.

Schneider, A. (1998). Why don't women publish as much as men? The Chronicle of Higher Education, September 11, 1-2.

Shere, W. \& Duhamel, R. (Eds.). (1987). Academic futures: Prospects for postsecondary education. Toronto, ON: Ontario Institute for Studies in Education.

Sheinin, R. (1998). The changing space for women in academe: The engender-ing of knowledge. In J. Stalker J. \& S. Prentice (Eds.), The illusion of inclusion: Women in postsecondary education, (pp. 216-230). Halifax, NS: Fernwood Publishing.

Stalker, J., \& Prentice, S. (Eds.). (1998). The illusion of inclusion: Women in postsecondary education. Halifax, NS: Fernwood Publishing.

The University of Calgary. (1998). The University of Calgary Fact Book (1997-1998). Calgary, AB: The University of Calgary.

Tomm, W., \& Hamilton G. (Eds.). (1988). Gender bias in scholarship. Calgary: Institute for the Humanities, The University of Calgary.

United Nations. (1992). Women in politics and decision-making in the late twentieth century. New York, NY: United Nations.

Xie, Y., \& Shauman, K.A. (1998). Sex differences in research productivity: new evidence about an old puzzle. American Sociological Review 63, 847-860. 